\title{
Multiple and recurrent inflammatory fibroid polyps in a Devon family ('Devon polyposis syndrome'): an update
}

\author{
R O Allibone, J K Nanson, P P Anthony
}

\begin{abstract}
Inflammatory fibroid polyps are uncommon but well documented as solitary polyps occurring typically in the stomach or ileum. A Devon family has previously been reported in which a female in three successive generations has presented with multiple polyps requiring repeated surgery over a number of years. A further two female family members, both siblings from the 3 rd generation, who required surgery for the same condition are now reported.
\end{abstract}

The term 'inflammatory fibroid polyp' is now generally accepted and is regarded as distinct from eosinophilic gastroenteritis and other conditions with which it had been previously confused. ${ }^{1}$ The lesions may present at any age and they have always been recorded as solitary, except in one case, ${ }^{2}$ and possibly in another, in which a second polyp was resected from the site of anastomosis of the previous operation six months before. ${ }^{3}$ The most common site is the stomach, followed by the ileum, and rarely the colon, duodenum, and oesophagus. The lesion consists of loosely arranged fibrovascular connective tissue with a variable inflammatory infiltrate including eosinophils. ${ }^{4}$ The aetiology remains unknown.

Multiple and recurrent inflammatory fibroid polyps in three generations of a Devon family were reported in $1984 .{ }^{5}$ One female was affected in each generation. Despite full documentation and reference in a review article, ${ }^{6}$ no further instances of a familial occurrence of this condition have come to light and this family remains unique. Within the last year, two sisters in the third generation have presented with small bowel obstruction as a result of identical lesions and have had to undergo surgery.

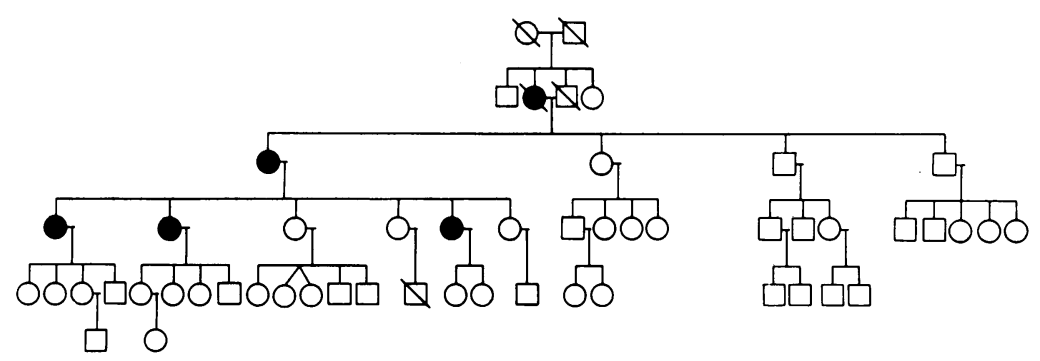

Updated family tree showing affected family members together with the fourth and fifth generations.

Departments of Pathology and Surgery, Hospital and Exeter

R O Allibone

J K Nanson

Correspondence to:

Dr R O Allibone, Area

Department of Pathology,

Church Lane, Heavitree,

Accepted for publication 21 October 1991
Case histories

The family tree is shown in the Figure. The two new patients are referred to as cases 4 and 5 .

CASE 4

This woman aged 30 years presented in 1990 with an ileocolic intussusception which required a limited right hemicolectomy. The head of the intussusception was found to be an ileal polyp just proximal to the ileocaecal valve which measured $4.5 \mathrm{~cm}$ with a $1.5 \mathrm{~cm}$ stalk. She had a history of hospital admissions for similar symptoms in 1976, 1983, and 1989 which resolved spontaneously.

CASE 5

This woman was aged 39 years. She gave a two month history of symptoms typical of intermittent small bowel obstruction before requiring a limited right hemicolectomy. A polyp, $3 \mathrm{~cm}$ in diameter on a $1.5 \mathrm{~cm}$ stalk, was found $17 \mathrm{~cm}$ from the ileocaecal valve.

Apart from a moderate increase in the white cell count in both patients, the results of routine investigations were normal. Histological examination showed typical inflammatory fibroid polyps, identical to those seen previously in cases 1,2 , and 3. Chromosome analysis on peripheral blood from cases 4 and 5, as previously undertaken in cases 2 and 3, showed no abnormality. Repeated questioning of other family members, including 4th and 5th generations, about dietary fads and gastrointestinal problems gave no pointer to a possible aetiology.

\section{Discussion}

The number of family members affected now stands at five, and a number of tentative observations can be made. Clinical expression of the disorder is still confined to the female line but, for the first time, two siblings of the 3rd generation have developed clinically symptomatic lesions. No members of the 4 th or 5 th generations are yet affected, though males and females of the 4th generation have now reached adulthood and will soon reach the youngest age at which the first operation took place in an affected family member. There are a number of differences between the five cases (Table). Case 1 was the only patient who had gastric lesions, all lesions since have been ileal. The age of presentation is earliest in the 3rd generation with one presentation (case 3 ) at 22 years and a second (case 4 ) with a history suggesting the presence of a polyp at the age of either 16 or 23 years. There is an apparent decrease in the number of polyps affecting 
Comparison of affected family members

\begin{tabular}{|c|c|c|c|c|c|}
\hline Case no & $\begin{array}{l}\text { Age at first } \\
\text { operation (yrs) }\end{array}$ & $\begin{array}{l}\text { Present age } \\
\text { (yrs) }\end{array}$ & $\begin{array}{l}\text { Duration of } \\
\text { symptoms }\end{array}$ & $\begin{array}{l}\text { No of } \\
\text { polyps }\end{array}$ & $\begin{array}{l}\text { No of } \\
\text { operations }\end{array}$ \\
\hline 1 & 59 & Died at 70 & Short & $\begin{array}{l}9 \text { (3 gastric: } 6 \\
\text { ileal) }\end{array}$ & 4 over 11 years \\
\hline $\begin{array}{l}2 \\
3 \\
4\end{array}$ & $\begin{array}{l}35 \\
22 \\
30\end{array}$ & $\begin{array}{l}62 \\
38 \\
31\end{array}$ & $\begin{array}{l}\text { Short } \\
3 \text { Days } \\
\text { Long, possibly } 14 \\
\text { years }\end{array}$ & $\begin{array}{l}7 \text { (all ileal) } \\
6 \text { (all ileal) } \\
1 \text { (ileal) }\end{array}$ & $\begin{array}{l}4 \text { over } 18 \text { years } \\
2,6 \text { years apart } \\
1\end{array}$ \\
\hline 5 & 39 & 40 & 2 Months & 1 (ileal) & 1 \\
\hline
\end{tabular}

each family member, but this may not be a valid observation due to the ages of the three daughters affected and the pattern of recurrence over many years (18 years in case 2 ). The length of the history in case 4, who had been admitted to hospital with identical symptoms on three previous occasions suggests that either the polyps are extremely slow growing or that they may even regress. Investigations, notably chromosome analysis of two more affected members, have remained fruitless. With only four living members of a single affected family, the opportunity to identify the abnormal chromosome by looking for linkage to other phenotypes does not exist, and thus more specific molecular tech- niques to pinpoint gene abnormalities cannot be undertaken. However, the pattern of affected family members makes an autosomal dominant mode of inheritance probable, though $\mathrm{X}$ linked inheritance cannot be excluded. The family is a large one, most members are engaged in rural occupations within the same location, and they are not concerned. Offers of screening by $x$ rays or endoscopy have not been taken up and we can only await further events.

We wish to thank Dr C Garrett for advice on the clinical genetics of this family.

1 Johnstone JM, Morson BC. Inflammatory fibroid polyp of the gastrointestinal tract. Histopathology 1978; $2 ; 349-61$.

2 Balmer F, Stucki P, Pedrinis P, Halter F. Tumoren und eosinophile granulome des dunndarms bei malabsorption. eosinophile granulome des dunndarms b

3 McGreery P, Doberneck RC, McLeay JM, Miller FA Recurrent eosinophilic infiltrate (granuloma) of the ileum causing intussusception in a two year old child. Pediatr Surg 1967; 61: $280-4$

4 Navas-Palacios JJ, Colina-Rinzdelgado F, Sanchez-Larrera MD, Cortes-Casino J. Inflammatory fibroid polyps of the gastrointestinal tract. An immunohistochemical and electron microscopic study. Cancer 1983; 51: 1682-90.

5 Anthony PP, Morris DS, Vowles KDJ. Multiple and recurrent inflammatory fibroid polyps in three generations of a Devon family: a new syndrome. Gut 1984; 25: 854-62.

6 Haggitt RC, Reid BJ. Hereditary gastrointestinal polyposis syndromes. Am $\mathcal{F}$ Surg Pathol 1986; 10: 871-87. 